\title{
NA CONTRAMÃo, SÓ QUE NÃO! \\ REFLEXÕES PESSOAIS SOBRE O USO DE FERRAMENTAS PARA AUXÍLIO NO ENSINO DO COMPONENTE CURRICULAR BIOLOGIA PARA O ENSINO MÉDIO
}

\author{
Sonia Aparecida Gurgueira Barca ${ }^{1}$
}

Lá estava ela, a "professora de Biologia", uma estranha àquela comunidade escolar, que por mérito e, talvez, também por obra do destino, aventurava-se a lecionar no ensino médio. Era possível ver naqueles rostos adolescentes a grande expectativa em relação ao que seria ofertado. Os recursos eram poucos: havia um espaço físico destinado ao laboratório de Ciências da Natureza destinado às aulas práticas dos componentes curriculares Química, Física e Biologia, mas que era mais adequado apenas a algumas aulas práticas de Química. O quadro era de giz, mas havia data show e notebook em número suficiente para os docentes, sem necessidade de reserva. Ótimo! Então lá foi a professora "armada" dessa tecnologia e conhecimentos tentar atender a tanta expectativa.

O começo foi interessante: as tradicionais aulas expositivas dialogadas com uso de multimídia sobre a "Origem da Vida", com informações que eles acharam muito engraçadas e classificaram como ingênua a Abiogênese, uma das primeiras teorias sobre o surgimento da vida. Os alunos gostaram muito da apresentação do método científico, que seguia o exemplo do livro didático (AMABIS \& MARTHO, 2013a, p. 16) sobre como o "bicho de goiaba" entra na goiaba. Primeiramente, "bicho de goiaba" é a fase larval da mosca da fruta "aprendizes de Biólogo". A professora informou que, em breve, eles teriam a oportunidade de praticar o conhecimento. Eles também gostaram de saber sobre o embate entre a Abiogênese e a Biogênese e sobre como Pasteur aplicou muito bem o método científico, ganhando até um prêmio em dinheiro. Com isso, criou um método tão eficiente para eliminar microrganismos de alguns alimentos, sem alterar seu sabor, e prolongou o tempo para consumo que é usado até hoje: a pasteurização (AMABIS \& MARTHO, 2013a, p. 34). Dá-lhe Biogênese!

Depois veio "O tempo Geológico" (AMABIS \& MARTHO, 2013b, p. 249) e ela precisou anotar tanta curiosidade e interesse na Era Mesozoica com os períodos Triássico e Jurássico, uma vez que todos queriam falar e saber sobre dinossauros. Pensou “Obrigada, Hollywood!". E usou as anotações para ajudá-los posteriormente, na compreensão de clonagem, já que vários queriam saber se era possível tornar real o filme Parque dos Dinossauros. Eles ficaram de assistir à película novamente e sugeriram uma seção de cinema no auditório, mas a professora informou que, por questões de logística, seria melhor que eles se reunissem em grupos na casa de alguns deles mesmos para rever o filme. O mais importante era entender o raciocínio humano para explicar que todas as eras estavam relacionadas à origem e evolução dos organismos, de acordo com a visão da ciência.

Para ela tudo parecia bom, mas, na realidade, o assunto era interessante. Mas veio o tédio! Porque, com tanta informação visual, os alunos pareciam ter dificuldade em imaginar os desenhos e esquemas apresentados por ela sobre membrana celular, modelo mosaico fluido, célula animal, célula vegetal e seus organoides celulares. E agora?

Corre para a "santa" internet, "fonte de saber e engano", e não é que ela encontra no sítio do YouTube um vídeo "super-mega-blast-hiper" interessante - nas suas próprias palavras. Uma animação intitulada "The Inner Life of Cell; A vida no Interior da Célula", produzida, em 2006, por uma equipe da Harvard's BioVision e da XVIVO Scientific Animation. A professora se apaixonou!

\footnotetext{
${ }^{1}$ E-mail: sonia.barca@etec.sp.gov.br.
} 
Tão superlativa! Os alunos tiveram reações muito divertidas, tais como admiração e repulsa. Vários deles disseram "Nem por sonho que essas coisas acontecem dentro do meu corpo" ou "Credo, esse lisossomo é nojento! Parece mais um monstro" e outras coisas assim. Então, ensinar ficou relativamente fácil: ir pausando e mostrando o passo a passo. Os estudantes disseram "agora deu para ver e entender o tal modelo mosaico fluido das membranas celulares com suas proteínas e fosfolipídios, que desenhados no quadro parecem bonecos e no vídeo também!", além dos organoides celulares como o Complexo Golgiense, as mitocôndrias, os lisossomos etc.

Ela sabe que o uso de vídeos em sala de aula obviamente não é novidade, mas é uma ferramenta muito útil que complementa a aula expositiva dialogada e ajuda a internalizar o conhecimento (MORÁN, 1995). Os alunos foram orientados a procurar na internet ferramentas como músicas para ajudar a memorizar tanta informação. Uma delas se tornou sucesso absoluto para memorizar as funções dos principais organoides celulares. A princípio, a professora se pegou, a contragosto, cantarolando "mitocôndria, mitocôndria é quem faz respiração..." (GRAÇA, 2012).

Novamente, foi muito bom ver na prática pessoal mais uma ferramenta útil. Paródias têm sido utilizadas no ensino Biologia, pois dinamizam a compreensão e do conteúdo (SILVA et al, 2015). Porém, ela sempre comenta aquele tal vídeo sobre a vida no interior das células, pois ainda não se decidiu se gosta mais da animação ou da trilha sonora. Parece que ela gosta de ambos e eles, também. Nem tanto professora!

Um desafio a mais que tinha que resolver era com a divisão celular. Outra animação permitiu visualizar as fases da mitose e se entender as semelhanças e diferenças entre mitose e meiose. Isso auxiliou na aula expositiva dialogada, mas os alunos não conseguiam memorizar os nomes das fases com as dicas sobre associar o evento da fase com seu nome. "Muitos nomes, em Biologia, têm origem grega", dizia ela. Também os lembrava de que disse, no início do ano: "Você aprende Biologia e terá, ao final das três séries, totalmente grátis, sem nenhum custo adicional, um curso de Grego".

Foi nesse momento que ela se lembrou de que, quando estudante do ensino médio, o professor de Biologia lhe ensinou uma frase mnemônica "ProMeti a Ana lhe Telefonar"... assim ficou fácil para os alunos memorizarem "Prófase, Metáfase, Anáfase e Telófase" e unirem toda a informação de vídeo e aula, internalizando o conhecimento. Tão velho e tão prático! Seus alunos resolveram dar upgrade e ficou "ProMeto a Ana que Telefono". E não é que ficou legal!

O uso da mnemônica já foi mais presente em salas de aula, mas parece que ficou mais restrito a cursos preparatórios. Não existe comprovação científica quanto à validade dessa técnica, mas ela sabidamente ajuda na memorização, cujo conceito já tenha sido entendido (CARRETEIRO, 2003; SILVA, 2009; SALES, 2015).

A professora também fez uso de atividades lúdicas, como a dramatização de um polímero. Ela promoveu todos a aminoácidos, que são moléculas orgânicas que representam as unidades monoméricas das proteínas, pediu que dessem as mãos, como analogia às ligações peptídicas que ocorrem entre os aminoácidos e, formassem um polipeptídio de aminoácidos, o que ajudou bastante a entender o conceito de polímeros (TAPIA \& FITA, 2015).

Mais adiante, nas aulas sobre Ecologia com foco em Ciclo da Matéria, ela usou a prometida aula prática, aproveitando o espaço do laboratório. "Não temos microscópios", ela pensou, "mas é possível visualizar a ação dos organismos decompositores e, de quebra, vivenciar o método científico! Além disso, eles precisam entender porque devem auxiliar seus pais na conservação dos alimentos perecíveis, guardando-os de forma adequada na geladeira ou congelador". Ela, então, trouxe bananas e copos plásticos de requeijão reutilizados para um experimento, incentivando seus alunos a elaborar hipóteses sobre como os pedaços de banana se apresentariam, armazenados nesses copos com tampa após uma e duas semanas. Como seriam, em relação ao aspecto, odor e cor, já que uns ficariam na bancada do laboratório (temperatura ambiente), sem qualquer adição de outros 
ingredientes; alguns seriam cobertos por uma generosa camada de açúcar; outros ficariam na geladeira; outros, no congelador. As hipóteses seriam posteriormente confrontadas com os resultados obtidos e surgiriam as conclusões.

O uso dos copos plásticos já serviu também de alerta quanto à diminuição da produção de resíduos, pois ganharam outra utilidade e, após a finalização, poderiam ser guardados para novos ensaios experimentais. "E eles perceberam a intenção sem precisar falar", pensou ela satisfeita, "como são espertos esses meninos e meninas!".

Aulas práticas são ótimas ferramentas no ensino de Biologia (LIMA \& GARCIA, 2011; SOARES \& BAIOTTO, 2015) e isso é comprovado na realidade dessa professora. mas ela ainda não conseguiu um número suficiente delas. Assim, para, digamos, "fechar com chave de ouro" sua disciplina, ela lançou mão de outro vídeo. Este mostrava a ação dos microrganismos decompositores (ASSIS, 2013) no tópico "organismos ex vivo e o ciclo da matéria", que poderia se transformar em composto para hortas domiciliares e na escola. Imediatamente, vários alunos ficaram motivados a ingressar e participar ativamente do projeto de produção de composto que estava em andamento na disciplina de Técnicas Organizacionais. Isso renderia outras histórias.

Vários outros vídeos vieram para tornar suas aulas mais encantadoras: o canto do uirapuru (AQUARIOSMASTER, 2009), ave símbolo do Amazonas, corou o estudo dos Domínios Morfoclimáticos do Brasil, ainda mais com a informação da lenda de que quem ouve o seu canto terá felicidade para sempre... e ela estava ofertando "totalmente grátis", como bônus pelo interesse e participação de seus caros alunos. Outras lendas do uirapuru que contou em aula ajudaram os alunos a perceberem que a intervenção humana na natureza ocorre às vezes, por motivos fúteis, como: prosperidade, se o homem tiver em sua posse uma pena do pássaro, ou um marido fiel e amoroso para toda a vida, se a mulher conseguir um pedaço do ninho (RESENDE, 2015). Lendas estas que levaram o pobre uirapuru a ficar em vias de extinção.

Bem, a história da nossa professora de Biologia não termina aqui e tampouco é tão resumida. Ela continua se encantando com sua profissão, feliz pela escolha de exercer o magistério para alunos do ensino médio em uma Escola Técnica. A educadora segue combinando o novo, na forma dos vídeos e imagens que encontra na internet, com o velho, o quadro de giz, as frases mnemônicas e os conhecimentos presentes nos livros didáticos, algumas aulas práticas e por aí vai. Todos se divertem e aprendem, e ela faz questão de frisar que é quem se diverte mais. Isso eu já não sei. O fato é que, a cada dia, cresce um pouco a pequena lista daqueles que também querem se formar Biólogos e auxiliar na preservação do planeta, assim como aconteceu com ela no ensino médio. É viver para ver!

\section{Referências}

AQUARIOSMASTER. O Canto do uirapuru verdadeiro (Cyphorhinus aradus). 2009. Disponível em: 〈https://www.youtube.com/watch?v=1ptgWSpK_RU>. Acesso em: 12 ago. 2017.

AMABIS, J. M.; MARTHO, G. R. Como a vida surgiu?. Biologia em Contexto, 1. ed., São Paulo: Editora Moderna, 2013a, cap. 5, vol. 1, p. 32- 34.

. A origem de novas espécies e dos grandes grupos de seres vivos. Biologia em Contexto, 1. ed., São Paulo: Editora Moderna, vol. 2, p. 249-271, 2013 b.

ASSIS, A. de L. Decompositores. 2013. Disponível em: <https://www.youtube.com/watch?v=Vdagly4nkLA $>$. Acesso em: 12 ago. 2017. 
GRAÇA, L. Organelas unplugged. 2012. Disponível em: <https://www.youtube.com/watch?v=P7pKup4mplA >. Acesso em: 12 ago. 2017.

LIMA, D. B.; GARCIA, R. N. Uma investigação sobre a importância das aulas práticas de Biologia no Ensino Médio. Cadernos de Aplicação, n. 24, p. 201-224, 2011.

MÓRAN, JOSÉ M. O vídeo na sala de aula. Comunicação e Educação, n. 2; p. 27-35, 1995.

RESENDE, L. A lenda do Uirapuru, o pássaro mágico que traz muita sorte. 2015. Disponível em: 〈http://www.xapuri.info/cultura/mitoselendas/o-uirapuru/>. Acesso em: 12 ago. 2017.

SILVA, S. P da; Pereira, I. B.; Melo, S. M. F de. O uso da música no ensino de Biologia: experiências com paródias. In: I CONGRESSO DE INOVAÇÃO PEDAGÓGICA, 2015, Arapiraca, Alagoas.

SILVA, S. M. S. O uso de técnicas mnemônicas como auxiliares no ensino-aprendizagem da Lingua Inglesa. Curso de Letras da Faculdade de Ciências, Educação e Letras da Universidade Vale do Rio Doce, Governador Valadares, MG, 2009.

SOARES, R. M.; BAIOTTO, C. R. Aulas práticas de biologia: suas aplicações e o contraponto desta prática.Revista Di@Logus, n. 4 (2), p. 53-68, 2015.

TAPIA, J. A.; FITA, E. C. A Motivação em Sala de Aula: o que é, como se faz. Tradução de Sandra Garcia. São Paulo: Edições Loyola, 2015.

XVIVO Scientific Animation \& Harvard's BioVision. The Inner Life of Cell, 2006. Disponível em: 〈http://www.xvivo.net/animation/the-inner-life- Of-the-cell / \# sthash.CdO6H4Mf.dpuf >; <https://www.youtube.com/watch?v=qW9_Sq2vSPc $>$. Acesso em: 12 ago. 2017. 